\title{
O labirinto da escuta
}

\section{The Listening Labyrinth}

\section{El labirinto de la escucha}

Caroline Alciones de Oliveira Leite *

http://dx.doi.org/10.22409/poiesis.1931.157-178

\begin{abstract}
RESUMO: Esta pesquisa investiga a obra Liverbeatlespool (2004) do artista Cildo Meireles, buscando compreender a relação entre som e imagens a partir do artista e teórico Rodolfo Caesar. A percepção da obra de arte e de suas sonoridades se apresenta como preponderante para esta pesquisa. Para tanto, recorremos a algumas formulações do filósofo Maurice Merleau-Ponty em sua coletânea Conversas e em seu livro A Prosa do Mundo. A partir da instalação da obra em loop, investigamos a repetição com o suporte das ideias do filósofo brasileiro Hilan Bensusan e de algumas questões propostas por Gilles Deleuze e Félix Guattari. Por fim, cabe observar que a própria escrita desta pesquisa guarda, em alguma medida, movimentos de repetição, buscando aprofundar, em cada linha, a escuta das imagens de Liverbeatlespool.
\end{abstract}

PALAVRAS-CHAVE: Liverbeatlespool; Cildo Meireles; imagens; som; repetição

\footnotetext{
* Caroline Alciones de Oliveira Leite é doutoranda do Programa de Pós-Graduação em Artes Visuais da Escola de Belas Artes da UFRJ, na linha de pesquisa História e Teoria da Arte. É mestre em Estudos Contemporâneos das Artes pelo Programa de Pós-Graduação em Estudos Contemporâneos das Artes (PPGCA) da Universidade Federal Fluminense, Niterói. E-mail: alcionesdol@gmail.com
} 
ABSTRACT: This research investigates the piece Liverbeatlespool (2004) by the artist Cildo Meireles, seeking to understand the relation between sound and images according to ideas by the artist and theorist Rodolfo Caesar. The perception of the work of art and its sonorities presents itself as preponderant for this research. For this reason, we have recourse to some formulations of the philosopher Maurice Merleau-Ponty in his collection Conversas and in his book The Prose of the World. From the installation of the work through a loop, we investigate the repetition with the support of the ideas by the Brazilian philosopher Hilan Bensusan and some questions proposed by Gilles Deleuze and Felix Guattari. Finally, it should be noted that the very writing of this research keeps, to some extent, movements of repetition, seeking to deepen, in each line, the listening of the images of Liverbeatlespool.

KEYWORDS: Liverbeatlespool; Cildo Meireles; images; sound; repetition

RESUMEN: Esta investigación trata de la obra Liverbeatlespool (2004) de autoría del artista Cildo Meireles, buscando comprender la relación entre sonido e imágenes a partir del artista y teórico Rodolfo Caesar. La percepción de la obra de arte y de sus sonoridades se presenta como preponderante para esta investigación. Para tanto, recurrimos a algunas formulaciones del filósofo Maurice Merleau-Ponty en su colección Conversaciones y en su libro La Prosa del Mundo. A partir de la instalación de la obra a través de un bucle, investigamos la repetición con el soporte de las ideas del filósofo brasileño Hilan Bensusan y de algunas cuestiones propuestas por Gilles Deleuze y Félix Guattari. Por último, cabe observar que la propia escritura de esta investigación guarda, en alguna medida, movimientos de repetición, buscando profundizar, en cada línea, la escucha de las imágenes de Liverbeatlespool.

PALABRAS CLAVE: Liverbeatlespool; Cildo Meireles; imágenes; sonido; repetición

Recebido: 21/3/2018; Aprovado: 14/4/2018

Como citar: LEITE, Caroline A. O. O labirinto da escuta. Poiésis, Niterói, v. 19, n. 31, p. 157-178, jan./jun. 2018.

doi: http://dx.doi.org/10.22409/poiesis.1931.157-178

Poiésis, Niterói, v. 19, n. 31, jan./jun. 2018. 


\section{O labirinto da escuta}

Hey Jude, Don't be afraid ${ }^{1}$

Convidado para participar da Bienal de Liverpool (2004), Cildo Meireles constatou o quanto a cidade localizada ao noroeste da Inglaterra o remetia, contundentemente, a uma das bandas mais famosas do mundo - The Beatles - formada em 1960. O artista pensou, inicialmente, em mixar e sobrepor todas as músicas gravadas pelo grupo britânico, compondo uma espécie de sólido. O aglomerado de músicas seria reproduzido em alto-falantes direcionados para a rua e fixados a parapeitos de janelas do segundo andar de prédios na região da rua Penny Lane e do orfanato Strawberry Field, localidades com as quais a banda possuía relação e em uma referência ao procedimento análogo que, segundo o artista, teria sido empregado por porto-riquenhos no Lower East Side (Manhattan) - memória do período em que Cildo Meireles morou em Nova York. 
A obra, no entanto, ganharia outro formato a partir de restrições legais quanto aos direitos de reprodução das músicas dos Beatles, propriedade de Michael Jackson à época. As negociações possíveis permitiram a utilização das músicas do disco The Beatles One, lançado em novembro de 2000 com vinte e sete canções do grupo, tendo alcançado o topo dos discos mais vendidos no mundo. A mixagem, feita a partir da parceria entre Cildo Meireles e seu filho Pedro Ariel, teve como fio condutor Hey Jude ${ }^{2}$, a música mais longa do disco, com 7 minutos e 11 segundos; a mixagem recebeu trechos de outras músicas incluídas no disco, da mais longa a mais curta, utilizando um software backword que permitia que duas músicas tocassem ao mesmo tempo e em sentidos inversos ou de forma linear e alternadas. (MEIRELES, 2009) A instalação da obra também precisou ser repensada, pois o desejo inicial do artista de espalhar sua obra pela cidade também esbarrou em questões legais que encareceriam e inviabilizariam a obra.

O artista, no entanto, encontrou uma forma de driblar as dificuldades para espalhar sua obra por Liverpool. No contexto da exposição Cildo Meireles, Geografia do Brasil, inaugurada em dezembro de 2001 no Museu de Arte Moderna Aloísio Magalhães, em Recife, Cildo Meireles tivera contato com bicicletas que possuíam alto-falantes acoplados e que circulavam pela cidade - a lembrança se transformou em estratégia para viabilizar sua obra em Liverpool. Um jovem artista, estudante recém-graduado, andaria com uma bicicleta com um alto-falante instalado que reproduziria Liverbeatlespool (2004) pela cidade de Liverpool, enquanto na Tate Liverpool, um dos espaços que acolhia a Bienal, havia um headphone através do qual era possível escutar a obra de Cildo Meireles. Tanto na Tate quanto na bicicleta o som tocava em looping. O título da obra também parece ter passado por um processo de mixagem, sendo o nome do grupo Beatles incrustado no meio do nome da cidade, operação que refletia a relação que o artista fazia, e que possivelmente muitos fazem, da cidade com o grupo britânico.

As imagens da obra de Cildo Meireles na Bienal de Liverpool contrastam, porém, com sua reedição treze anos mais tarde, no contexto da exposição Lugares do Delírio realizada no Museu de Arte do Rio (MAR) ${ }^{3}$, em fevereiro de 2017. Na cidade do Rio de Janeiro, o $D j$

Poiésis, Niterói, v. 19, n. 31, jan./jun. 2018. 
Stylus Baratona, um senhor que costuma circular pela Zona Portuária da cidade com um veículo adaptado - uma espécie de triciclo, com tanque de motocicleta e sistema de altofalantes - veiculando anúncios de serviços, levou em sua garupa Liverbeatlespool pela região, fizesse chuva ou sol, naqueles meses de final de verão. Dentro do MAR, outras obras de Cildo Meireles foram instaladas em um ambiente escurecido onde havia projeção de imagens da série de 42 fotografias São Cottolengo, cédulas do projeto Zero Real (2013), ao lado de obras de videoinstalação e de instalação sonora de quatro artistas Marc Pataut, Dudu Mafra, Mauricio Dias e Walter Riedweg.

Enquanto na Tate Liverpool, era possível escutar a obra somente em pé, já que não havia cadeiras, na exposição curada por Tania Rivera, ao contrário, o headphone foi pendurado a uma parede na qual havia uma cadeira que aguardava, discretamente, aqueles que quisessem conhecer Liverbeatlespool. A escuta da obra naquela instalação dificilmente se daria a partir do início exato da banda sonora; no entanto, a surpresa se daria quando, ao sentar na cadeira e colocar o aparelho nos ouvidos em uma espécie de isolamento do mundo, o visitante ouvisse o som dos Beatles preparado por Cildo Meireles e anunciado no título da obra, e mais: o som de outra obra do artista - Sal sem Carne (1975). Uma surpresa escondida, marcando um ponto de partida ou de chegada, quebrando a sequência de dez loops de Liverbeatlespool e conferindo um elemento a mais à sedução promovida pela repetição, pela escuta em loop. Finalmente, Hey Jude começava a tocar, apenas em um dos lados do headphone; enquanto a música familiar domina um dos ouvidos, no outro o som mixado começa a se apresentar, em um primeiro momento em um volume baixo, quase tímido, nos induzindo a seguir os comandos da canção: "Hey Jude, don't make it bad / Take a sad song and make it better / Remember to let her into your heart / Then you can start to make it better". (Paul McCartney, 1968) Cildo Meireles se apropriou da canção que tentava alegrar Julian Lennon (e sua mãe Cynthia) diante da separação de John Lennon e a transformou em outra obra de arte; também nós somos convidadosseduzidos a pegar a canção e a embarcar na obra e em sua repetição. 
Como em uma espécie de hipnose, parece haver uma sugestão para que os olhos se cerrem e os ouvidos possam ser aguçados para a mixagem que se sobrepõe à canção, tomando conta do espaço, não o expositivo, mas aquele pequeno e ao mesmo tempo infinito espaço que se abre entre um fone e outro do headphone, nos induzindo a olhar para dentro e a buscar o som dentro de nós. A canção dos Beatles se arrefece em meio ao turbilhão da mixagem que, cada vez mais, se apossa do espaço até que, da música, passamos a ter como referencial apenas as batidas do pandeiro meia-lua, como se estivéssemos em alto mar, no meio da noite e, vez por outra, um farol nos sinalizasse que há ali, um porto, o fio de Ariadne que nos guiará pelo labirinto - Hey Jude, Don't be afraid.

Sem que necessariamente se cante em conjunto com a obra, tarefa que talvez não seja possível, Hey Jude na obra de Cildo Meireles remete à importância do ato de cantarolar no escuro para a criança, algo observado pelo filósofo Gilles Deleuze como forma de tranquilizar e de estabelecer algum início de ordem no caos. A canção no escuro possibilita que a criança se situe no mundo, no caos do escuro, conferindo certa tranquilidade ante um território que se constrói a partir da própria voz ou daqueles que a ninam. Talvez aí tenhamos a primeira noção de caos e de território seguro, de caos e de lar, entre os ouvidos e a escuta da própria voz, entre os ouvidos e a escuta daqueles que formam nos braços o laço que embala o lar, a noção de porto-seguro ante o mundo que se abre ao fechar os olhos e no qual somente há o sujeito, ainda que recém-chegado ao mundo.

Liverbeatlespool (Fig. 1, 2, 3 e 4) instaura um idioma estranho que não conseguimos identificar, uma espécie de som do universo, do mundo, um som que está dentro de nós, em nossa cabeça, pescando ou resgatando imagens distintas, como a do emaranhado linguístico da escuta de uma língua estranha e completamente desconhecida, como os cantos gregorianos para quem não fala grego, como o som dos antigos aparelhos de ultrassom investigando um bebê, ou mesmo os sons daquele mundo projetado por Stanley Kubrick em 2001: A Space Odissey.

Poiésis, Niterói, v. 19, n. 31, jan./jun. 2018. 

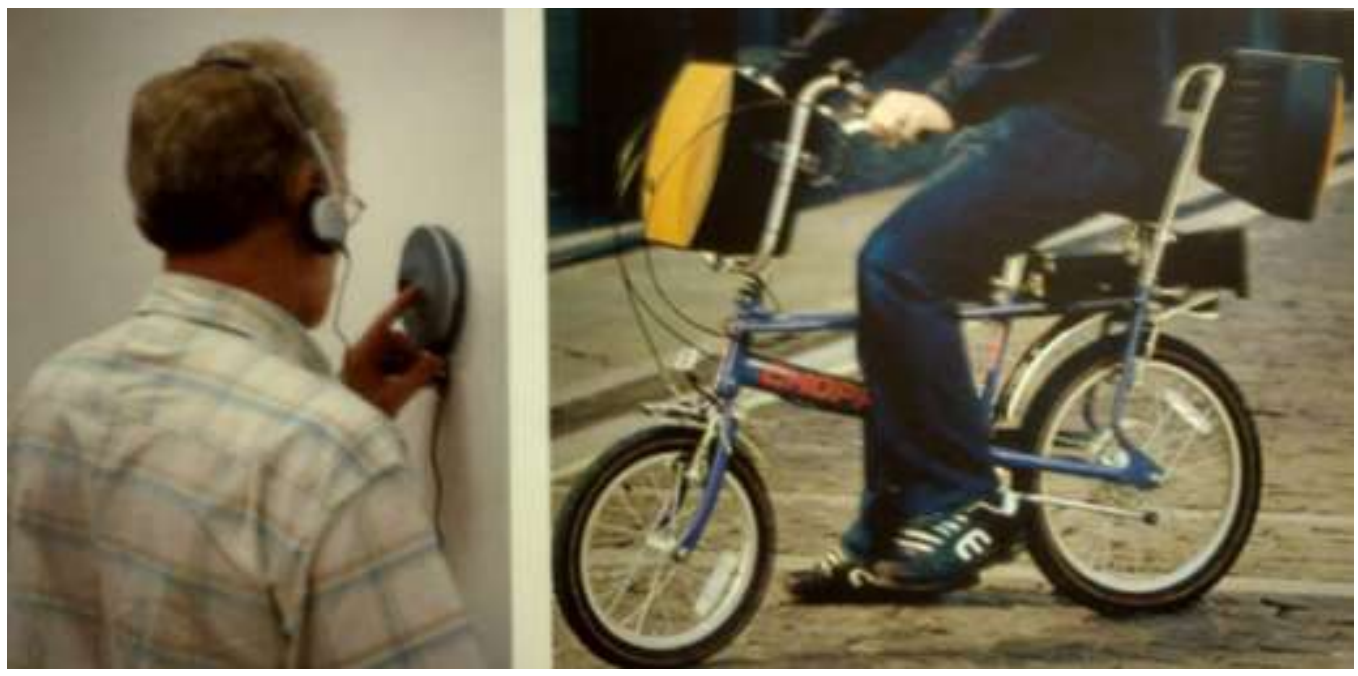

Fig. 1 - Cildo Meireles, Liverbeatlespool, 2004.

(Fonte: Catálogo da exposição Cildo Meireles, 2013)

Poiésis, Niterói, v. 19, n. 31, jan./jun. 2018. 

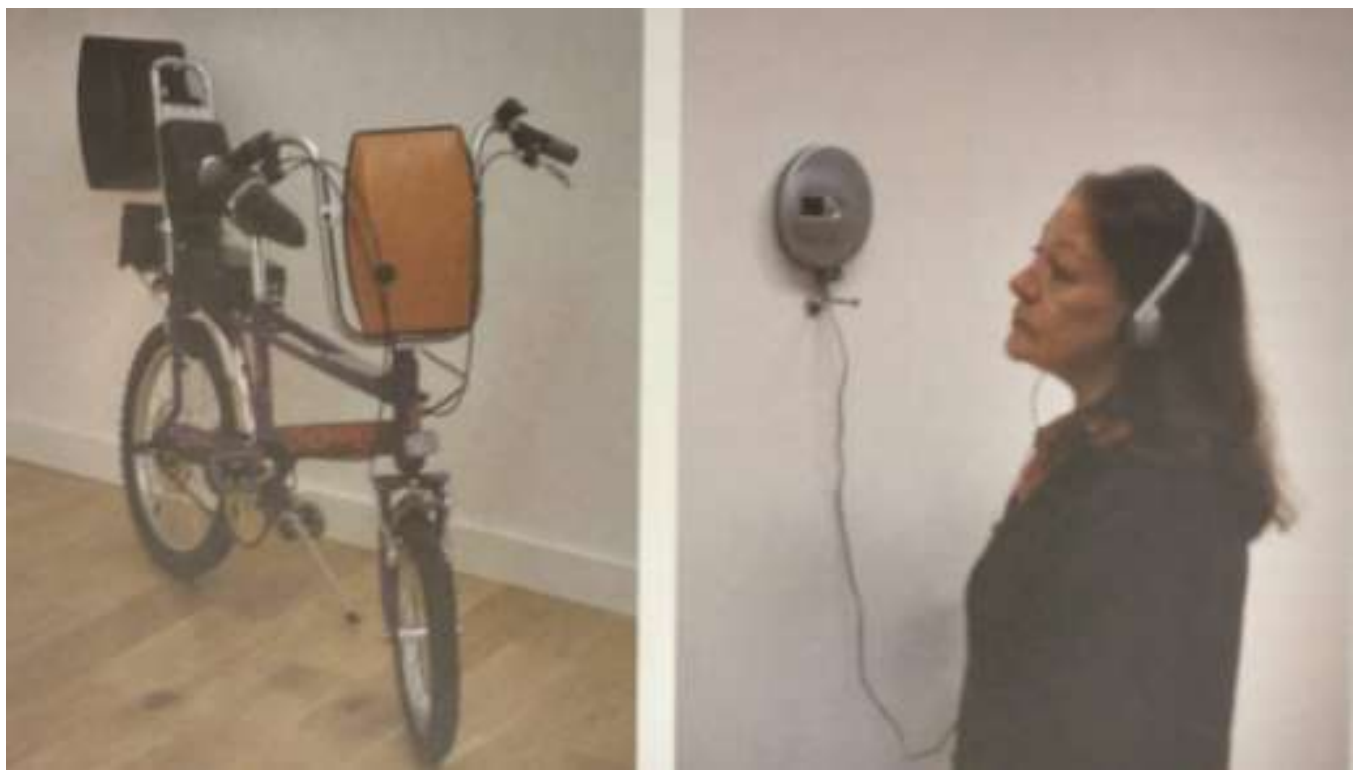

Fig. 2 - Cildo Meireles, Liverbeatlespool, 2004

(Fonte: Catálogo da exposição Cildo Meireles: Installations, 2014)

Poiésis, Niterói, v. 19, n. 31, jan./jun. 2018. 

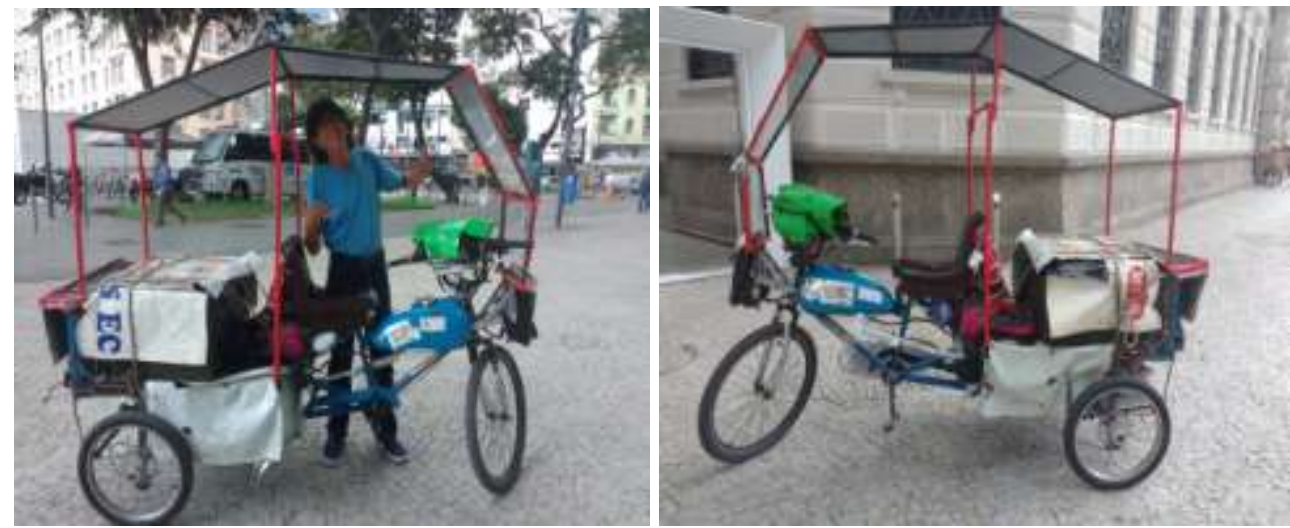

Fig. 3 - Cildo Meireles, Liverbeatlespool, 2004.

Exposição Lugares do Delírio, no Museu de Arte do Rio (MAR)

(Fonte: Arquivos da autora, 2017) 
166

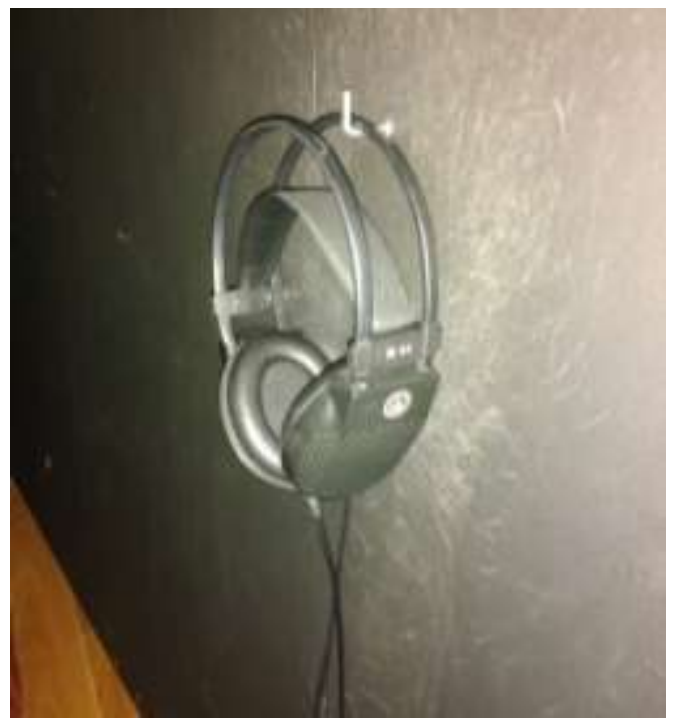

Fig. 4 - Cildo Meireles, Liverbeatlespool, 2004.

Exposição Lugares do Delírio, no Museu de Arte do Rio (MAR)

(Fonte: Arquivos da autora, 2017)

Poiésis, Niterói, v. 19, n. 31, jan./jun. 2018. 
Nah, nah, nah, nah nah nah, nah nah nah, hey Jude

Há, ainda, o aspecto da inversão da música em Liverbeatlespool observado pela psicanalista e ensaísta Tania Rivera, em seu livro O Avesso do Imaginário, ao contar que, durante sua estada em Nova York, Cildo Meireles conheceu Andy Hosey, um matemático e músico que teria passado longos anos em uma instituição psiquiátrica e que teria contado ao artista sobre a existência de músicas eruditas de altíssima qualidade, como algumas de Beethoven, que conservariam "uma estrutura espelhada, de tal modo que se poderia, ao atingir o meio da peça, tocá-la ao contrário." (RIVERA, 2013, p. 358) A autora observava neste fato a existência de uma estrutura topológica da música que teria conduzido Cildo Meireles à sua ideia de inversão/espelhamento em Liverbeatlespool. A questão topológica parecia se manifestar também na decisão por inundar o espaço urbano - de Liverpool, que possui uma zona portuária importante em sua história e, anos adiante, da Zona Portuária do Rio de Janeiro - e o espaço interno dos ouvidos que ousaram se encontrar com a banda sonora produzida pelo artista em parceria com seu filho.

A proposta de Cildo Meireles de trabalhar com certo espelhamento não se localiza na esfera da objetividade, de uma inversão pura da imagem em uma superfície que a carregue, como no filme fotográfico que revela uma imagem invertida, no espelho que ilusiona o reflexo sobre o aço ou como o fonógrafo capaz de gravar e reproduzir o som. O procedimento empregado por Cildo Meireles em Liverbeatlespool se assemelha à observação do narrador de $O$ Espelho ${ }^{4}$ que se dá conta, a partir de sua figura invertida, que sua feição seria constituída pela sobreposição de uma série de máscaras a espelhar animais e elementos hereditários, espécie de lastro evolutivo de avós e pais que, ao fim e ao cabo, juntas compunham aquela estranha imagem que o personagem-narrador, no espelho do banheiro de um prédio público, mirava, estranhava, não reconhecia e se punha a descontruir. Em Liverbeatlespool, o artista brincou com noções de identificação e de estranhamento, ao valer-se de músicas conhecidas ao redor do mundo de uma forma que as tornasse indiscerníveis ao mesmo tempo em que uma matriz era conservada - Hey Jude. Não há mais a canção original, mas a sobreposição de singles dos Beatles que se espalharam pelo mundo. 
Não há o original porque a canção tocada através do suporte - o disco, a fita ou o DVD é sempre a reprodução, uma espécie de cópia sem o original. Afinal, o que seria o original de um disco, fita ou CD? A aura do objeto de arte a respeito da qual Walter Benjamin discorreu se esvanece quando a música é fixada em um suporte, estabelecendo proximidade entre o sujeito e a obra quando "o coro, [que] executa numa sala ou ao ar livre, pode ser ouvido num quarto" a partir da técnica que "permite à reprodução vir ao encontro do espectador, em todas as situações, [e que] atualiza o objeto reproduzido." (BENJAMIN, 1987 p. 168-169) As formulações de Benjamin nos remetem à reflexão do teórico e artista Rodolfo Caesar de que

é a isso que se resume a imagem refletida de Narciso: uma cópia sem o original: exatamente conforme a noção proposta por Mario Perniola para designar a imagem produzida pelos meios de comunicação de massa: "não possui original - trata-se de uma construção artificial que não possui protótipo". Narciso precisou só de uma superfície espelhada para constituir sua imagem. Bastou-Ihe uma água parada para que se desdobrasse em loops repetindo al go que era cópia em estado original. (CAESAR, 2012, p. 43)

Cildo Meireles se apropria dos singles mais tocados dos rapazes de Liverpool e faz uma colagem que dialoga diretamente com a ideia que ecoa em sua mente quando escuta o nome da cidade britânica. Se para a ninfa Eco a repetição foi uma maldição que contribuiu para mantê-la distante de Narciso, para o artista representou uma forma de intensificar questões, de gravar sua obra no CD e de buscar seduzir o ouvinte a manter-se na obra.

A canção principal se espelha, por um lado, e aglutina-se com as outras canções, refletindo uma imagem possível da cidade. As músicas mais pedidas nas rádios do mundo e o disco que figura entre os mais vendidos evidenciam também uma repetição das canções da banda pelo mundo e no interior dos ouvidos de sujeitos que escutaram os Beatles, nos fazendo recordar a estratégia utilizada pelos gregos para se reconhecerem como gregos conhecer os versos homéricos da Ilíada e da Odisseia. Para tal, "a repetição presente já nos poemas pré-homéricos serviria como procedimento de fixação na memória, esse suporte dinâmico ao alcance de quem tem a massa cinzenta necessária para o armazenamento, o processamento e a transmissão de 'imagens'". (CAESAR, 2012, p. 40)

Poiésis, Niterói, v. 19, n. 31, jan./jun. 2018. 
De acordo com o filósofo brasileiro Hilan Bensusan, a repetição teria força não através de conexões necessárias, mas através de partes do mundo real a moldar outros mundos. $\mathrm{Pa}$ ra o filósofo, ao invés de algo universal guiado por necessidades subjacentes, a repetição teria a capacidade de definir o mesmo padrão para coisas concretas a partir do contágio; assim, padrões locais em coisas concretas afetariam aquilo que se encontra ao redor, fazendo emergir uma universalidade a partir do contato. (BENSUSAN, 2016) Nestes termos, os padrões de repetição esculpiriam a mídia que se faz disponível, vulnerável à repetição, mesmo que essa mídia seja a própria expectativa humana;

Os padrões são eles próprios escultores de qualquer meio que esteja aberto a eles - eles não são interferências abstratas, mas podem ser transmitidos de uma coisa concreta para outra. Um desses meios é a expectativa humana: somos gravados com o hábito de esperar algo se somos sensíveis ao que é repetido. (BENSUSAN, 2016, p. 165, tradução nossa)

Cildo Meireles esculpiu um condensado de canções dos Beatles, fundindo uma ideia de Liverpool às canções mais tocadas do grupo e, ao mesmo tempo, intrigando a expectativa de sujeitos de ouvir Hey Jude, fazendo com que a cada novo loop do condensado fosse possível perceber elementos novos, identificar trechos de músicas distintas ou, simplesmente, se deixar levar pelo todo.

A partir de Bensusan, podemos inferir que a universalidade residiria na repetição, uma vez que, enquanto não há a repetição de algo, esse algo é único, não sendo, portanto, universal. Mas a partir do momento em que padrões de repetição se instauram, a partir do momento em que características básicas se repetem, cria-se o cenário propício para o estabelecimento da universalidade. Talvez, neste sentido, a repetição das músicas dos Beatles tocadas, em várias partes do mundo, se configurasse como um dos meios ou estratégia que permitiu que a banda se tornasse mundialmente famosa - reconhecida. Em alguma medida, as músicas carregam algo em comum que parece bailar com a universalidade - o disparo de questões, sentimentos, sensações nos mais distintos sujeitos e um movimento que começa pelos ouvidos em direção a um mundo interior.

Poiésis, Niterói, v. 19, n. 31, jan./jun. 2018. 
Bensusan resgata a noção de repetição nua e de repetição vestida de Gilles Deleuze, observando a impossibilidade de uma repetição restaurar o original, instaurar o expressamente igual. Neste sentido, a repetição vestida viria modulada por fatores inesperados e microvariações inevitáveis. (BENSUSAN, 2016) Liverbeatlespool parece refletir, portanto, as questões de uma repetição vestida: na medida em que o aglomerado sônico repete trechos de músicas, que já foram exaustivamente tocadas nas rádios, de forma extremamente adereçada, permitindo novas percepções de uma matriz primeira composta pelos Beatles. Também a repetição do aglomerado Liverbeatlespool se tornar vestida a cada vez que se tem a oportunidade de incorrer em sua escuta. A partir de um primeiro contato com a obra, os ouvidos podem se tornar mais atentos e partir em busca de novos elementos no aglomerado, uma repetição que pode induzir a cerrar os olhos na busca, inconsciente que seja, por aguçar a audição e poder escutar melhor as imagens sonoras que se desdobram e se desenrolam dentro do espaço aberto pelo cair das pálpebras ou, tão somente, no olhar para dentro. Talvez, neste sentido, Rodolfo Caesar tenha afirmado que a imagem sonora é uma forma de imagem mental, o que não significa visualizar algo através da escuta, mas de compreender que através da escuta formam-se imagens da mesma forma que é possível formar imagens a partir da visão.

Bensusan observa também que a repetição se dá no tempo, uma vez que para haver repetição é necessário que aquilo que se repete tenha sido criado em um momento anterior, permitindo, segundo Deleuze, que se compreenda o passado, o presente e o futuro em termos de repetição. (BENSUSAN, 2016) O passado preparou o momento presente e a repetição seria tanto o que vem se repetindo como o que foi ensaiado,

0 presente é o que repete. É moldado pelo passado. 0 presente é o momento de ressonância; é quando as expectativas são postas para trabal har e quando repetições passadas conferem ritmo ao que está por vir. 0 presente é 0 repetidor: 0 que traz o que foi ensaiado para atuar. Finalmente, o futuro é 0 repetido -0 que pode ser previsto é o que esteve presente em repetições passadas. 0 futuro aparece como o que se repete, o que é programado pelo hábito, o que é induzido. Não há futuro sem indução. (BENSUSAN, 2016, p. 166, tradução nossa)

Poiésis, Niterói, v. 19, n. 31, jan./jun. 2018. 
Talvez haja, ainda, outra instância de repetição, uma na qual o processo de criação de Cildo Meireles pode ser compreendido como o instante do presente, aquele em que o artista permite que memórias e questões recorrentes finalmente passem a se apresentar sob a perspectiva da arte. O futuro dessas repetições se encarregaria de materializar a obra de arte, um resultado da representação de questões do passado no presente. Não seria, portanto, uma repetição sob a perspectiva do igual, do semelhante, não se trataria de uma repetição nua; mas antes, de repetições vestidas pelos adereços do tempo que permitem que o artista depure questões, tome decisões a partir daquilo que, repetidamente, toma conta de seus pensamentos e que o afetam.

A obra de Cildo Meireles evidencia algo discutido pelo artista e teórico Giuliano Obici, para quem a repetição pode ser compreendida como

uma estratégia de tornar o código durável. Daí sua presença no espaço, ponto de ligação entre o espaço e o tempo. 0 que permanece, marca e delimita um espaço, que as características do som, assim como as espaciais, pressupõem. A persistência de um código sonoro seria uma forma de "devir espaço" do tempo. (OBIC, 2008, p. 65)

Cildo Meireles empregou em sua obra algo que se mantém no tempo, fazendo reverberar a repetição de músicas dos Beatles de forma singular e valendo-se deste mecanismo dentro do aglomerado, mas também a partir da repetição em loop proposta tanto para a bicicleta quanto para o headphone. Uma repetição que comove os ouvidos através do impacto da obra cujo som "se faz 'interno', existindo em nossa consciência, a partir de quando o percebemos. Ele existe simultaneamente fora e dentro da consciência." (OBICI, 2008, p. 28) Estabelece-se, assim, um tempo próprio da obra a se autodeterminar a partir da disponibilidade de cada sujeito à escuta da obra.

\section{Remember to let her under your skin}

Liverbeatlespool funda dentro de si um espaço próprio de escuta. A obra que circula pela cidade deixa um rastro daquilo que seria a obra, dando mostras do que é, pitadas de obra 
no tempo-espaço urbano, uma forma de seduzir e enfeitiçar ouvidos atentos e disponíveis a encontrar o aglomerado sônico no headphone instalado na Tate Liverpool ou no MAR; um encontro quase-improvável, mas disponível a acontecer. Fosse a partir da perseguição do som que circulou pela cidade e que, no caso da exposição no MAR, vez por outra aportava na entrada do museu; fosse em um encontro mais imediato com a obra a partir dos headphones, o fato é que Liverbeatlespool parece instaurar um tempo-espaço peculiar a badalar de acordo e em disponibilidade aos ouvidos que a ela se entregam.

O artista norte-americano Peter Halley, em seu texto After Art, observa que nos anos 1960 a gravação fonográfica se tornou uma das formas de arte mais populares. Através da gravação fonográfica, parecia se oferecer uma promessa de imortalidade, diante da qual, grandes estrelas da gravação pareciam acelerar o fim de suas vidas para passar à eternidade exclusiva dos discos. (1988) Neste sentido, o artista e teórico Rodolfo Caesar observa que para Jonathan Sterne

o nascimento da gravação sonora teria oferecido um atrativo mortuário: a possibilidade de registrar vozes que pudessem ser escutadas depois que seus donos morressem. Menciona o caso de Nipper, o cão da publicidade da RCA Victor, ouvindo a voz de seu dono, possivelmente morto no caixão sobre o qual se apoiam o cão e seu gramofone. (CAESAR, 2012, p. 38)

Este bailar da arte com a morte encontra na gravação sonora a possibilidade de travessia entre mundos, de driblar o tempo e fazer ressuscitar um momento que já se foi através do som, ao estabelecer um pacto com Caronte, o barqueiro de Hades, que passa a trazer o som do mundo dos mortos, ganhando, por sua vez, a oportunidade de encontrar-se com a arte. O som gravado confere aos ouvidos a possibilidade de viajar no tempo através de sentimentos e de sensações por ele disparados.

Essa viagem no tempo, no entanto, somente parece possível a partir de processos de transdução, da passagem do som de um meio para o outro, viabilizando ao sujeito um encontro com a arte. A mixagem executada por Cildo Meireles e seu filho Ariel precisa encontrar os ouvidos, indo além da pele do sujeito. Daquele meio acústico que o som se instaura

Poiésis, Niterói, v. 19, n. 31, jan./jun. 2018. 
entre o headphone e o ouvido é necessário o toque na pele, é necessário que a escuta se dê a partir do encontro entre som e ouvidos, de forma a viabilizar a decodificação do meio acústico para impulsos elétricos cerebrais que se decodificarão, novamente, nos mais abstratos sentimentos, pensamentos e sensações a partir de uma experiência que nos lance em nosso interior, gravando imagens sonoras em nós; o sujeito é, portanto, o disco à espera da fixação do som. Vale observar que no texto Acerca do Ritornelo, Deleuze e Guattari discorrem sobre a existência dos meios exterior, interior, intermediário e anexado,

0 vivo tem um meio exterior que remete aos materiais; um meio interior que remete aos elementos componentes e substâncias compostas; um meio intermediário que remete às membranas e limites; um meio anexado que remete às fontes de energia e às percepções-ações. Cada meio é codificado, definindo-se um código pela repetição periódica; mas cada código é um estado perpétuo de transcodificação ou de transdução. A transcodificação ou transdução éa maneira pela qual um meio serve de base para um outro ou, ao contrário, se estabelece sobre um outro, se dissipa ou se constitui no outro. (DELEUZE, GUATTARI, 2007, p. 118-119)

A obra de Cildo Meireles parece promover um convite a uma transcodificação ou transdução a partir do estabelecimento de meios que se dissipam e se constituem em um outro. De acordo com Bensusan, "a transdução em um cenário orientado pelo ritmo é o que conecta coisas concretas independentes - elas são expostas aos ritmos do fluxo de informações". (2016, p. 177, tradução nossa) Assim, talvez seja possível relacionar Liverbeatlespool com a transdução a partir de uma perspectiva alargada, uma na qual seja possível observar a passagem do som dos headphones para uma escuta interior e desta para as imagens sonoras que, assim, se constituem na percepção do sujeito sobre a obra de Cildo Meireles.

A propósito das sete conferências encomendadas ao filósofo francês Maurice MerleauPonty pela Rádio Nacional Francesa e transmitidas pela rede Programa Nacional de Radiodifusão Francesa (RDF) ao final de 1948, transformadas adiante na coletânea Conversas, o filósofo elaborou sobre o fato de corpo e espírito não serem partes constitutivas do homem; antes, o homem seria um espírito com um corpo, o que Ihe permitiria alcançar a 
verdade das coisas pelo fato de seu corpo ser cravado nas coisas. Assim, "o homem está investido nas coisas, e as coisas estão investidas nele." (MERLEAU-PONTY, 2004, p. 24) A obra de Cildo Meireles se apossa do artista em seu ato de criação, podendo também se apossar do sujeito que com ela se relaciona, cravando-se no espírito que a reconhece e reverberando por veredas desconhecidas e impensáveis, uma vez que "a obra de arte é vista ou ouvida, e nenhuma definição, nenhuma análise ulterior, por mais preciosa que possa ser posteriormente e para fazer o inventário dessa experiência, conseguiria substituir a experiência perceptiva e direta que tive com relação a ela." (MERLEAU-PONTY, 2004, p. 57)

Se para o filósofo francês "todo outro é um outro eu mesmo" (MERLEAU-PONTY, 2012, p. 219), haveria, porém, um eu capaz de destituir a posição central, um eu descentrado, um eu capaz de inverter os papéis entre aquele que vê e aquilo que é visto. De repente, a coisa toma a propriedade de ver. O derramamento de Liverbeatlespool pelos ouvidos do sujeito se estabelece a partir de uma percepção da sonoridade da obra através da qual o descentramento do eu se torna possível a partir de um mergulho da coisa em si e de si na coisa. Trata-se de uma experiência individual e que, em alguma medida, parece se distanciar da elaboração de Merleau-Ponty sobre a relação que se estabelece com o outro e que confere ao sujeito, a partir de um espelhamento, os reflexos daquilo que o constitui. Do headphone para dentro, Liverbeatlespool pode promover um descentramento do eu, novamente, como o narrador do conto de Guimarães Rosa que, ao fixar com determinação seus olhos na figura que encontrava no espelho, descentrou-se a tal ponto que não via mais reflexo algum no espelho, nem mesmo de seus olhos, sendo necessário, aos poucos e com cautela, constituir, e não restituir, uma nova fisionomia, distante das máscaras de identificação com tantos outros.

A obra de Cildo Meireles parece suscitar um olhar para dentro e um descentramento do sujeito a partir de um engajamento com o mundo, algo possível a partir da escuta no contexto artístico. A artista e escritora Salomé Voegelin observa a escuta distante de um modo de recepção, localizando-a como um método de exploração, através do qual é pos-

Poiésis, Niterói, v. 19, n. 31, jan./jun. 2018. 
sível caminhar sobre paisagens sonoras, e compreendendo a escuta como descoberta e não como recepção. A descoberta é, portanto, produtiva capaz de gerar fantasias - "entre meu ouvido e o objeto/fenômeno sonoro, eu nunca saberei sua verdade, mas posso tão somente inventá-lo, produzindo um conhecimento para mim." (VOEGELIN, 2010, p. 5, tradução nossa) A partir das sete conferências de Merleau-Ponty, Voegelin escreve Listening to Noise and Silence, ressaltando a proposta do filósofo francês, a respeito da pintura moderna, de se ver para além da expectativa intelectual de uma realidade representativa, propondo que a escuta de uma obra de arte deva acontecer da mesma forma - a partir do engajamento, da entrega do sujeito à escuta -, observando que o sentido fenomenológico de Merleau-Ponty "surge da sensação e não da racionalidade e transgride o coletivo através da construção de sentido individual." (2010, p. 11, tradução nossa)

Ao observar que o ato de escutar lança o sujeito no som, Voegelin reflete sobre uma relação na qual o objeto ou o fenômeno demandaria da escuta a cumplicidade e o compromisso. Porém, se por um lado a escuta de Liverbeatlespool pode se dar a partir do estabelecimento de uma cumplicidade e de um compromisso, instaurando-se uma escuta criativa, uma escuta em direção à sensação, libertando-se da racionalidade e em relação direta com o interior que se abre a partir da invasão do som derramado pelos ouvidos adentro, por outro lado, talvez essa escuta criativa possa se dar em outros termos. Talvez exista a possibilidade de uma escuta distraída ser tomada de tal forma por uma obra de arte que as noções de compromisso e engajamento não sejam necessariamente uma opção em se estabelecer um compromisso, mas uma impregnação que se instaura através da contundência daquilo que toma os ouvidos, independentemente do tempo de duração, e que pode continuar a reverberar no sujeito, mesmo após a retirada dos fones, como se a entrega do sujeito à escuta, o estabelecimento do compromisso, antes de ser uma escolha, fosse uma questão de vulnerabilidade e disponibilidade como Bensusan, em relação aos ritmos, compreende como entrainment ${ }^{5}$,

Porque os ritmos entrain, há pouco sentido em falar sobre ritmos intrínsecos. Os ciclos circadianos são entrained pela rotação da Terra, as marés são arrastadas pela lua, o ritmo menstrual de uma mulher é leva- 
do pelos ciclos de outras mulheres. 0 entrainment exibe características de um processo intensivo; trata-se de um processo de contágio indiferente aos agentes. É o que torna os ritmos intensivos: eles entrain aquilo que os rodeia de diferentes maneiras, dependendo da mídia em que a repetição ocorrerá. Ser entrainable é estar sujeito ao ritmo e são entrainable os componentes vibratórios da luz de laser, das reações químicas, das formações geológicas e dos ciclos orgânicos. (BENSUSAN, 2016, p. 168, tradução nossa)

Neste sentido, talvez seja possível observar, a partir de processos de entrainment, o estabelecimento de uma relação com a obra de arte através da escuta. Uma escuta cuja intensidade pode se sobrepor a supostas vontades a partir do contato e do contágio de algo que previamente já estivesse presente no sujeito, provocando seu engajamento com uma obra como a de Cildo Meireles. Através do entrainment o sujeito pode ser transportado para o espaço de percepção da obra.

Assim, Liverbeatlespool talvez demande um recuo ou, simplesmente, um movimento em direção à subjetividade, à possibilidade de existir, paradoxalmente, a partir de certo afastamento de si e de seu aglomerado sônico. E, desse recuo, se torna possível o emergir de novas questões, novas obras, novas percepções de mundo, e mesmo de um "ainda-nemrosto - quase delineado, apenas - mal emergindo, qual uma flor pelágica, de nascimento abissal..." (GUIMARÃES ROSA, 2005, p. 120)

\section{So let it out and let it in}

Em momentos nos quais a visualidade das artes parecem não dar conta de determinadas imagens, Cildo Meireles, em seus processos de distanciamento, recorre ao som como possibilidade de instaurar uma nova natureza de imagem, uma que não se fixa, mas que possui movimento, velocidade, que corre e escorre pelos ouvidos. Ao contrário de uma correlação entre imagem visual e som, Liverbeatlespool parece impor que o sujeito mergulhe em si, em sua subjetividade e em suas questões, sugerindo que a escuta pode ser uma possibilidade de existência tanto naquilo que diz respeito aos sujeitos quanto às artes.

Poiésis, Niterói, v. 19, n. 31, jan./jun. 2018. 
A repetição na escuta de Liverbeatlespool não instaura o igual; antes, parece estabelecer um mesmo padrão através do contágio a afetar aqueles que têm os ouvidos tocados pela repetição disponíveis a se contaminar, aprofundando a escuta através do loop, navegando em um labirinto que se abre ao olhar para dentro. Liverbeatlespool dá a ver que aos estímulos do mundo, as respostas de Cildo Meireles não são apressadas, mas guardadas naquele local cujo distanciamento permite uma ampla percepção que retorna como uma obra de arte que convida a refinar a escuta e a embarcar em mundos sônicos existentes na subjetividade, na abstração e no descentramento de cada sujeito.

\section{Referências}

BENSUSAN, Hilan. Being Up for Grabs: On Speculative Anarcheology. Londres: Open Humanities Press, 2016.

BENJAMIN, Walter. A obra de arte na era de sua reprodutibilidade técnica. In Walter Benjamin: magia e técnica, arte e política. Obras escolhidas (vol. 1). São Paulo: Editora Brasiliense, 1987.

CAESAR, Rodolfo. O som como é: imagem; água e ar, seus suportes. In Pelas Vias da dúvida: $2^{\circ}$ Encontro de Pesquisadores dos Programas de Pós-Graduação em Artes do Estado do Rio de Janeiro. Rio de Janeiro: Escola de Belas Artes, 2012.

DELEUZE, Gilles; GUATTARI, Félix. Acerca do ritornelo. In Mil Platôs: capitalismo e esquizofrenia (vol. 4). São Paulo: Editora 34, 2007.

HALLEY, Peter. [1985] After Art. In Peter Halley collected essas 1981-1987. Zurique: Bruno Bischofberger, 1988. (tradução publicada na revista Poiésis, Niterói, v. 18, n. 30, p. 109-116, 2017)

MEIRELES, Cildo. Memórias. Entrevistador: Felipe Scovino [2007]. In: SCOVINO, Felipe (Org.). Cildo Meireles (coleção Encontros). Rio de Janeiro: Beco do Azougue, 2009, p. 234-291.

MERLEAU-PONTY, Maurice. Conversas: 1948. São Paulo: Martins Fontes, 2004. 
MERLEAU-PONTY, Maurice. A prosa do mundo. São Paulo: Cosac Naify, 2012.

MUSEU DE ARTE CONTEMPORÂNEA DE SERRALVES. Cildo Meireles. (catálogo de exposição). Porto, Portugal; São Paulo: Fundação de Serralves; Cosac Naify, 2013.

OBICI, Giuliano Lamberti. Condição da escuta: mídias e territórios sonoros. Rio de Janeiro: 7 Letras, 2008.

PIRELLI HANGAR BICOCCA. Cildo Meireles: Installations. (catálogo da exposição itinerante realizada na Pirelli Hangar Bicocca, Museo Nacional Centro de Arte Reina Sofía e Museu de Arte Contemporânea de Serralves). Milão, Madri e Porto: Mousse Publishing, 2014.

RIVERA, Tania. O avesso do imaginário: arte contemporânea e psicanálise. São Paulo: Cosac Naify, 2013.

GUIMARÃES ROSA, João. O espelho. In: Primeiras estórias. Rio de Janeiro: Nova Fronteira, 2005, p. 113-120.

VOEGELIN, Salomé. Listening. In Listening to Noise and Silence: Towards a Philosophy of Sound Art. Nova York: The Continuum International Publishing Group, 2010, p. 3-40.

\section{Notas}

\footnotetext{
${ }^{1}$ Os subcapítulos deste artigo são versos da canção Hey Jude de autoria de Paul McCartney, composta em 1968. Optamos por não traduzir os versos da canção, nem nos subcapítulos, nem quando citados no texto, como forma de preservar sua poesia e suas sonoridades.

${ }^{2}$ Canção composta por Paul McCartney em 1968.

${ }^{3}$ De abril a junho de 2018, a exposição Lugares do Delírio esteve na área de convivência do Sesc Pompeia.

${ }^{4} \mathrm{O}$ Espelho é o décimo primeiro conto do livro Primeiras estórias no qual João Guimarães Rosa narra contos que se espelham a partir do conto central do livro.

${ }^{5}$ Optou-se por não traduzir as palavras entrainment, entrain, entrained e entrainable por acreditarmos que as expressões comportam, ao mesmo tempo, noções de encarrilhamento, de arrastar, de se deixar levar pelo contágio e de ressonância.
}

Poiésis, Niterói, v. 19, n. 31, jan./jun. 2018. 